\title{
PÔSOBENIE RÁDU SV. KLÁRY V UHORSKU A NA SLOVENSKU
}

\author{
The Order of Saint Clare in the Kingdom of Hungary and Slovakia
}

\author{
Mária Nemčeková
}

DOI: 10.17846/CL.2019.12.1.59-75

\begin{abstract}
NEMČEKOVÁ, Mária. The Order of Saint Clare in the Kingdom of Hungary and Slovakia. The period of the High Middle Ages was characterized by growth in many spheres of life and culture. While the growth and prosperity of those times are often taken for granted, the High Middle Ages was also the time of great human and religious unrests, when many attempts were made to create new forms of an exclusively religious life. These efforts led to the creation of countless religious movements among which the Franciscans and their affiliated order of nuns, the Poor Clares, have become the most significant. These pauperist movements followed and imitated Christ in strict poverty. The main protagonists of this movement were Saint Francis of Assisi and Saint Clare of Assisi who laid foundations of the two religious communities that bear their names. The Poor Clares were actively present in the territory of Slovakia from 1239 until 1782 when their order was dissolved. In 2001, the order of the Capuchin Poor Clares was established in Slovakia in Kopernica near Kremnica.
\end{abstract}

Keywords: the Franciscan movement, Poor Clares, Kingdom of Hungary, Slovakia

\begin{abstract}
Abstrakt: NEMČEKOVÁ, Mária. Pôsobenie Rádu sv. Kláry v Uhorsku a na Slovensku. Vrcholný stredovek sa na jednej strane vyznačoval velkým rozmachom $v$ rôznych podobách. A hoci sa konštatuje všestranný rozkvet, predsa možno toto obdobie zároveň označit za obdobie velkého ludského i náboženského nepokoja. Vyznačuje sa mnohými pokusmi o vytvorenie nových foriem radikálneho náboženského života, ktorý sa prejavil vo forme vzniku nespočetných náboženských hnutí. Spomedzi nich sa najvýraznejšie prejavuje františkánske hnutie a z neho odvodená rehola klarisiek. Tieto pauperistické hnutia (hnutia chudoby) sa vyznačovali verným nasledovaním Krista v prísnej chudobe. Hlavným protagonistom tohto hnutia bol sv. František a sv. Klára z Assisi, ktorí položili základ vzniku dvoch reholných spoločenstiev nesúcich ich meno. Klarisky pôsobili aj na Slovensku, a to od roku 1239 do roku 1782, ked' bola táto rehola zrušená. Od roku 2001 pôsobí na Slovensku nová rehola klarisiek kapucínok v Kopernici pri Kremnici.
\end{abstract}

Klúčové slová: františkánske hnutie, klarisky, Uhorsko, Slovensko

Hlavným cielom novovzniknutých náboženských hnutí vrcholného stredoveku bolo nasledovanie a napodobňovanie Krista, čo znamenalo zanechat všetko. Ideálom sa stal dokonale uskutočnený útek od sveta v askéze. Dominantnou tendenciou bolo spontánne prijatie tých najprísnejších foriem pokánia a odumretie svetu, čo bolo neodmyslitel’ným predpokladom na dosiahnutie svätosti (Zavalloni 2005, 15). 


\section{„Nóvum“ františkánskeho hnutia}

Navonok by sa mohlo zdat', že ideál sv. Františka je v jeho jednoduchosti a pokore, v tichosti a poslušnosti, vzdialený od buričských nálad predchádzajúcich hnutí a prúdov. A aj ked’ to znie čudne, ba až paradoxne, jediné nové, čo František znova prináša na svet a do života Cirkvi, je evanjelium (Manselli 1966, 134). Za podstatu evanjelia a základ krestanského života považuje predovšetkým chudobu. František sa zrieka všetkého nielen z poslušnosti voči evanjeliovým radám, ale aj preto, aby sa priblížil k chudobným, opusteným, malomocným, v ktorých vidí prítomného Krista. Nejde mu iba o odmietanie svetských dobier, ale predovšetkým o gesto bratstva, ktoré zdôraznilo silnejšiu vnútornú motiváciu krestanskej chudoby. František pochopil, že nestačí hladat chudobu len samu osebe, ale spolu s ňou aj milosrdenstvo a lásku (Esser, 1975, 260). Preto František vystupuje v dejinách Cirkvi ako nový človek a naozaj ním bol, lebo začal chápat chudobu i celý krestanský život novým spôsobom.

Františkova chudoba, osobná i komunitná, má jasný zmysel, lebo sa vztahuje na dobrovolnú účast na chudobe Krista a apoštolov. Išlo predovšetkým o chudobu „materiálnu“, reálnu, povzbudzovanú a udržiavanú duchovným odpútaním sa (Zavalloni 2005, 28).

Táto chudoba žije a živí sa slovami evanjelia, uskutočňuje a prejavuje sa vo výnimočnom psychickom a ludskom rozmere a v určitom historickom ovzduší.

\section{Ženské náboženské hnutia}

12. a 13. storočie je poznamenané aj vel'kým rozmachom ženských náboženských hnutí. Pri ich vzniku v kúrii vždy platila zásada: aby mohli spoločenstvá a hnutia zotrvať v štruktúre Cirkvi, čiže viest̉ náboženský život v pravom zmysle slova v úplnom a výlučnom odovzdaní sa náboženským úlohám a predpísaným životným formám, musia byt zabezpečené určitými pravidlami (regulami) a pevným poriadkom.

Podla tejto zásady sa kúria vždy snažila pričlenit’ všetky ženské náboženské hnutia do pevných foriem regulárnych rádov v presvedčení, že náboženský život môže mat̉ svoju pravú hodnotu až vtedy a len vtedy, ak je začlenený do univerzálneho, správneho ordo krestanského sveta (Grundmann 1961, 200).

Podla nariadenia Lateránskeho koncilu z roku 1215 mohlo náboženské hnutie dosiahnut' cirkevné uznanie iba vtedy, ak sa nechalo začlenit do foriem už existujúcich rádov. Ale vlastná forma rádu, ktorá by bola vhodná na prijatie velkého ženského náboženského hnutia, neexistovala. Vita religiosa bola vždy formovaná len pripojením sa do mužských kláštorov, v spojení s mníšskymi rádmi. Začlenenie ženského náboženského hnutia do cirkevných poriadkov sa teda mohlo uskutočnit iba pripojením k existujúcim mužským rádom (Sbaralea 1983, 201).

\section{Rád františkánov a ženské kláštory v 1. polovici 13. storočia}

František - zakladatel' spoločenstva potulných kazatelov, ktorý v roku 1210 dostal pápežské povolenie, nemal nikdy v úmysle založit ženský rád. Jasne sa to ukázalo práve pri Klárinom „obrátení“. Na Kvetnú nedelu v roku 1212 zavŕšila v Porciunkule v prítomnosti bratov svoju konverziu, rozdala svoj majetok (dedičstvo), odložila šperky, drahé šaty, zbavila sa svojich vlasov (tonzúra) a prijala „znaky svätého pokánia“ (Sbaralea 1983, 81). Na Františkovu radu sa prestahovala do kostola sv. Damiána pred bránami Assisi; budovu s kostolom prenechal biskup Guido z Assisi Františkovi na tento účel. Tam sa k nej čoskoro pripojili iné ženy a toto spoločenstvo žilo bez toho, že by sa zaviazalo nejakej regule iného rádu; žili podla Františkových usmernení a jeho rád v evanjeliovej 
chudobe a v podstatnom sa nelíšili od pôvodnej reguly prvých františkánov s výnimkou záväzku a povinností evanjeliových kázní (Sbaralea 1983, 243, 264). ${ }^{1}$ Je vel’mi pravdepodobné, že v dôsledku nariadení Lateránskeho koncilu spoločenstvo v San Damiano cítilo potrebu zadovážit si privilégium, aby si mohlo udržat zásadnú charizmu spočívajúcu v princípe prísnej chudoby. Súčasne s týmto úsilím sa budovala aj vnútorná štruktúra spoločenstva tým, že Klára bola vymenovaná za abatišu (Grundmann 1961, 254). ${ }^{2}$ Pravdepodobne v tom čase bola zavedená aj prísna klauzúra. Takto vznikol kláštor uznaný kúriou, ktorý sa od všetkých ostatných ženských kláštorov odlišoval tým, že sa zriekol akéhokolvek majetku, takže nežil z príjmov plynúcich z majetkov, ale bol presne tak, ako františkánske spoločenstvo, odkázaný na almužny alebo zárobok vlastnou prácou. František bol tomuto Klárinmu spoločenstvu v San Damiano s osobitnou láskou naklonený a chcel mu navždy zachovat priazeň a starostlivost' svojho rádu. ${ }^{3}$

Toto bol zároveň aj jediný ženský kláštor, ktorý on „založil“, ktorého vznik bezprostredne podnietil a ktorého príslušnost̉ k svojmu rádu si želal a uznal. Okrem San Damiano nemal byt podla jeho vôle do jeho rádu začlenený alebo jeho bratmi založený a podporovaný žiadny iný ženský kláštor. Všetkým pokusom previest' na jeho rád starostlivost’ o iné ženské kláštory sa vehementne postavil na odpor a bratom prísne zakázal prijímat ženy do rádu (Sbaralea 1983, 212). ${ }^{4}$

\section{KLARISKY V UHORSKU A NA SLOVENSKU}

Druhý rád sv. Františka - rád klarisiek - patrí k najstarším ženským rádom a od 13. storočia pôsobil aj na území Slovenska v Trnave a v Bratislave. V čase smrti sv. Kláry (1253) už bolo v celej Európe 150 klariských kláštorov (Duchoňová 2010,16).

Súčastou bohatej histórie stredovekých miest boli nepochybne mnohé mnišske rády, ktorých úlohou bolo aktívne pôsobit proti heretickým učeniam a modlit sa za jednotu a pevnost' Uhorského královstva. Jedným z nich bol kontemplatívny rád sestier svätej Kláry. Ich poslaním bolo podla vzoru svätého Františka žit’ v chudobe, čistote a poslušnosti (Duchoňová 2012, 16-19).

Klariskému hnutiu na Slovensku sa dlhé roky venovala a venuje PhDr. Klára Mészárosová, bývalá dlhoročná pracovníčka Západoslovenského múzea $\mathrm{v}$ Trnave a terajšia pracovníčka Univerzitnej knižnice v Bratislave. Skúmala pôsobenie tejto rehole na Slovensku; zozbierala cenné materiály a spracovávala ich do celkov, ktoré vychádzali v časopise „Novinky z radnice“ v Trnave. Za zmienku stojí kuriózna skutočnost', že tak budova Západoslovenského múzea v Trnave, ako aj budova Univerzitnej knižnice, čiže bývalé i súčasné pracovisko doktorky Mészárosovej sa nachádzajú v bývalých budovách kláštora klarisiek. Sama hovorí, že práve z tejto skutočnosti pramení aj jej záujem o túto reholu.

1 Táto Forma vivendi alebo „Formula vitae“, ktoré dal František sestrám v San Damiano sa spomína v Klárinej Regule z roku 1253, kap. VI a v Bule Gregora IX. Anežke Českej z 11. mája 1238.

2 Tri roky po svojom obrátení cogente beato Francisco suscepit tandem regimen dominarum.

3 Klárina Regula z roku 1253 uvádza slová Františkovej Forma vivendi pre San Damiano: „... Volo et premitto per me et fratres meos semper habere de vobis tamquam de ipsis curam diligentem et sollicitudinem specialem".

4 Pri rokovaniach s kardinálom Hugolínom v roku 1219 František vysvetloval: ,... preter unum illud, in quo Claram reclusit, nullum aliud se ex struxisse aut extrui procurasse atque ita huius solius curam assumpsisse tam quoad disciplinam regularem quam quoad tenuem victum mendicitate per se aut socios conquierendum. Neque quidquam sibi tandumdem displicere, quam ut fratres in aliis partibus monialibus domicilia constitui et per se regi impensius voluerint". 


\section{Klarisky v Trnave}

Kláštor klarisiek v Trnave bol založený už v roku 1239; priestory na svoje pôsobenie im poskytol král' Belo IV. Jeho sestra Alžbeta Durínska bola vellkou podporovatel'kou učenia svätého Františka z Assisi; nebola síce členkou rádu, ale žila podla ich kánonu. Zomrela v roku 1231 v chýre svätosti ešte počas života sv. Kláry. Pápež Gregor IX. ju vyhlásil za svätú štyri roky po jej smrti. Jej život velmi ovplyvnil trnavské ženy a dievčatá, ktoré koncom roka 1238 vytvorili skupinu sestier podla vzoru sv. Kláry. Potvrdenie založenia rehole získali listinou pápeža Gregora IX. z 20. mája 1239. Pápež v nej zobral pod ochranu trnavské mníšky rádu sv. Damiána (podla kostola sv. Damiána v Assisi). Zároveň získali kostolík zasvätený sv. Alžbete. Bélo IV. z úcty k svojej sestre daroval 11. mája 1240 sestrám rádu sv. Damiána dôchodky z dediny Boleráz a v roku 1247 vyňal Boleráz spod právomoci bratislavského župana aj trnavského richtára. Približne okolo roku 1255 bol postavený pôvodný kláštor a kostol zasvätený Blahoslavenej Panne Márii a Všetkým Svätým pri Lovčickej bráne, na mieste dnešnej budovy. Z historických dokumentov je známe, že názov rádu nebol koncom 13. storočia ešte jednotný napriek tomu, že v roku 1263 ho pápež Urban IV. zjednotil pod menom Ordo Sanctae Clarae (Duchoňová 2012, 16-19).

Kláštorný komplex spočiatku tvorila budova kostola a iba jedna obytná stavba. Jednolodový kostol mal presbytérium zaklenuté krížovou rebrovou klenbou a ukončené rovným uzáverom. V jeho južnej stene sa pri prieskume našla stredoveká sedília s kamennou obrubou a ornamentálnou freskou. Na kostol sa napájala mohutná obdľžniková budova - dnešné stredné kláštorné krídlo. Stavba mala pravdepodobne dve podlažia. Jej prvé podlažie bolo čiastočne zahíbené do terénu. Vedla kláštora stála jednoposchodová budova, v ktorej bývali kapláni slúžiaci omše (Čambál 2010, 101-102).

Kedže klarisky žili v klauzúre a nemali povolené žobrat', prostriedky na živobytie získavali vd’aka štedrej pomoci panovníkov a pápeža. V auguste 1251 ich zobral pod svoju ochranu pápež Inocent IV. a dovolil im vlastnit domy, pozemky a usadlosti získané darom. O mesiac neskôr im pápež zmiernil prísne rehol’né pravidlá a povolil im, aby v zimných mesiacoch mohli nosit kožušinový odev. Panovník Štefan V. oslobodil majetky klarisiek v bratislavskom komitáte od platenia daní a kolekty.

V rámci kláštorného života boli klarisky viazané prísnymi regulami, ktoré určovali ich povinnosti voči Bohu i rádu. Prvá čast’ regule - poslušnost’ - predpokladala oddanost’ Bohu a Cirkvi. Znamenalo to bezvýhradné rešpektovanie autority abatiše a rádových predstavených. Podla druhej časti regule - chudoby - dievča nemohlo pri vstupe do rádu vlastnit žiadny majetok; slub chudoby sa vztahoval na samotnú mníšku, ktorá si nesmela nič privlastňovat. Rodičia však vstupným darom kláštoru zadovážili hmotné zabezpečenie svojej dcéry - mníšky. Dary od príbuzných mohli prijat’ len so súhlasom predstavenej (Kušniráková 2011, 28-32).

Ďalšia čast’ regule upravovala otázku prijímania nových členiek do rádu. Podmienkou na vstup do kláštora bol vek 15 rokov a dobrý zdravotný stav. Za výchovu a formovanie dorastu zodpovedali majsterky noviciek. Po prijatí sa dievča podrobilo tonzúre a od tej chvíle nesmelo opustit kláštor ani komunikovat's okolitým svetom, čiže musela dodržiavat prísnu klauzúru. Prijat návštevu bolo povolené len so súhlasom abatiše a v prítomnosti „sestier načúvajúcich“, ktoré mali dohliadnut” na obsah rozhovoru. Mníšky prijímali návštevy v miestnosti na to určenej - v parlatóriu. Menšie dary sa podávali cez rotu - otočné zariadenie. Počet návštev v roku i čas ich trvania určovala regula rádu. Mníšky nesmeli pristupovat k oknám ani k bráne, aby nemohli viest̉ nekontrolované rozhovory s osobami zvonka. Každé z dievčat dostalo oblečenie, ktoré pozostávalo z habitu so škapuliarom. Podla vzoru bratov františkánov bol habit prepásaný povrazom nazývaným cingulum. $\mathrm{Na}$ ňom mali tri uzly - symbol troch evanjeliových rád - čistoty, chudoby a poslušnosti. Na hlave nosili biele rúško so závojom a čepiec z rovnakej látky ako bol habit. Denne sa osemkrát modlili 
liturgické hodinky: začínali o polnoci matutínom, pokračovali hodinkami laudes, prima, tertia, sexta, nona, vespera a kompletórium. Každý deň sa zúčastňovali bohoslužby. O ich duchovné potreby sa od roku 1296 starali františkánski mnísi. Regula stanovovala aj spôsob volby predstavenej a pracovné zadelenie členiek rádu. Funkčné obdobie predstavenej sa v priebehu čias menilo, zvyčajne to boli dva alebo tri roky. Predstavená kláštora - abatiša - zodpovedala za náboženský život reholnej komunity a reprezentovala kláštor vo vzt̉ahoch s vonkajším svetom. „Večnou“ matkou sa stala sestra, ktorá bola viackrát predstavenou kláštora. Zástupkyňou abatiše bola priorka, ktorá sa starala predovšetkým o majetkové a finančné záležitosti. Poradným zborom vedenia kláštora boli volené a večné diskrétky, ktoré spolurozhodovali najmä o prijímaní noviciek a o spravovaní kláštorného majetku. Prestížne postavenie v rehol’nej komunite patrilo aj mníškam dozerajúcim na dodržiavanie klauzúry a učitelkám, ktoré vychovávali rádový dorast. Uvedené posty zvyčajne získavali staršie, skúsenejšie mníšky. Každodenný chod kláštora zabezpečovali šafárky, správkyne vínnych pivníc, nemecké a madarské sekretárky, dirigentky, opatrovatelky chorých a kuchárky. Ďalšie funkcie boli napr. horné strážkyne dverí, dolné strážkyne dverí, počúvačky (pri návštevách), almužníčky, majsterky chorých, strážkyňa octu, cukrárky, šičky, záhradníčky, opatrovatelky ohňa, opatrovatel'ky budovy, atd'. Pochádzali zvyčajne z radov laických sestier, ktoré vstupovali do kláštora bez vena. Regula d’alej nariad’ovala dodržiavanie ticha - silencium - od Vel'kej noci až po sviatok Narodenia Panny Márie. Cez deň dodržiavali ticho od zvonenia na vešpery po tretiu kánonickú hodinku. Všetky povinnosti, ktoré v tom čase vykonávali, museli robit’ v tichosti a nemohli prijímat' návštevy. Regula upravovala spôsob zbierania a rozdávania almužny i opatrovanie chorých (Duchoňová 2012, 16-19).

Začiatkom 14. storočia boli sestry rádu svätej Kláry často nútené riešit mnohé sporné otázky týkajúce sa vyberania poplatkov zo svojich majetkov. Už v roku 1303 si od krála Ladislava V. dali potvrdit oslobodenie kláštora od platenia akýchkolvek daní a poplatkov. O rok neskôr ich od platenia desiatkov z kláštorných majetkov oslobodil pápež Benedikt IX. Napriek tomu došlo okolo roku 1309 k sporu, v ktorom sa klarisky stažovali ostrihomskému arcibiskupovi na neoprávnené vyberanie poplatkov Ostrihomskou kapitulou. Spor definitívne vyriešil pápežský legát kardinál Gentilis v prospech klarisiek (Duchoňová 2012, 16-19).

V roku 1325 život sestier nepriaznivo poznačil velký požiar v Trnave, ktorý poškodil aj kláštor a kostol klarisiek. Kedže klarisky nedisponovali dostatočnými prostriedkami na obnovu, žiadali finančnú pomoc od krála. Ďalšie prostriedky získali z pozemkov a majetkov, ktoré získali v obciach Hoste, Pavlice a Neštich (Roháč 2010, 98-100).

Koncom 14. storočia dokončili rekonštrukciu kostola, počas ktorej sa zmenil tvar presbytéria z rovného na polygonálny; do interiéru kostola bola vložená nová krížová klenba s kamennými rebrami a s výraznými konzolami figurálneho charakteru.

Spolu s prestavbou kostola bol pôdorysne rozšírený aj kláštor dovtedy pozostávajúci iba z jedného murovaného krídla. Zväčšili ho na typickú trojkrídlovú dispozíciu pristavanú k južnej stene kostola s otvorenou arkádovou chodbou - ambitom - lemujúcim rajský dvor - dnešné východné nádvorie (Čambál 2010, 101-102).

Počas husitských vojen obsadili majetky klarisiek bohatí meštania a vidiecka šlachta a poberali z nich príjmy. $\mathrm{V}$ tejto nepokojnej situácii boli klarisky nútené žiadat’ o pomoc pápeža. Pápež Urban VI. poveril trnavských františkánov z kláštora sv. Jakuba, aby vyriešili vrátenie obsadených majetkov. V júni 1432, ked’ sa husiti pod vedením Blažeka z Borotina dostali do mesta, trnavské klarisky museli utiect’ k sestrám klariskám do Bratislavy. Vrátili sa až v roku 1435 na príkaz krála Žigmunda. Pri požiari a rabovaní Trnavy husitmi bolo zničených a stratených vela listín a privilégií, ktoré klariskám patrili, preto vydal Král Matej Korvín privilégium, v ktorom dosvedčuje právoplatnost' nárokov na dedinu Boleráz (Varsík 1975, 122). 
Majetok klarisiek sa postupne zväčšoval vdaka štedrým darom od rôznych významných mecenášov, napríklad v roku 1479 odkázal klariskám dediny Biely Kostol a Fančal vážený pán Elefant Benedik. V roku 1524 im ostrihomský arcibiskup Ladislav Sálkaj podaroval desiatok z viníc v obci Smolenice. Po bitke pri Moháči sa mnohí feudáli zmocnili majetkov klarisiek a neprávom si nárokovali na desiatok $\mathrm{z}$ viníc $\mathrm{v}$ obciach Neštich a Boleráz. V tejto nepriaznivej situácii žiadali klarisky o pomoc mestskú radu. Na žiadost̉ mesta prikázal Ferdinand I. v roku 1544 Františkovi Ňárymu, aby vrátil klariskám les v Bolerázi a poveril ho spravovaním ich majetku. Ďalšie výhody získali v rokoch 1528, 1548 a 1549, ked král Ferdinand zakázal mestu, aby boli poddaní pracujúci na majetkoch mníšok nútení k verejným prácam. Mesto podporovalo vzrast kláštorných pozemkov v rámci mestských hraníc. V roku 1555 získali klarisky dedičstvo rodiny Salcer: záhrady pozdľž Dolnej brány. V roku 1627 im mesto darovalo vedla ležiaci pozemok. Daniel Lancer daroval klariskám záhradu a v roku 1668 Štefan Réčej dom so záhradou, ktorý stál oproti kláštoru. Na tieto donačné aktivity mala nemalý vplyv skutočnost', že medzi mníškami sa nachádzali členky významných uhorských šlachtických rodín. Svoje zastúpenie v kláštore mali rody Aponi, Erdödy, Forgáč, Révaj, Čáky, Barkóci, Beréni. Bežným javom bolo, že v kláštore žili blízke príbuzné, tety so svojimi neterami, sesternice i sestry. Rodiny, ktoré mali v kláštore príbuzné, boli štedrými mecenášmi a donátormi kláštora. Jednou z takých rodín boli Forgáčovci. Isté je, že budova klarisiek bola začiatkom 17. storočia v dezolátnom stave, lebo z roku 1607 sú známe žiadosti mníšok královskej komore o podporu na jej reštaurovanie. Už v roku 1608 bol postavený a ostrihomským arcibiskupom grófom Františkom Forgáčom vysvätený nový oltár, do ktorého boli vložené relikvie svätých Lörinca, Antala a Gála. Katarína Pálfiová, vdova po jeho bratovi Žigmundovi, palatínovi Uhorska (1618 - 1621) povolila v roku 1649, aby na časti jej majetku v Trnave viedla nová cesta a pozemok pod pôvodnou cestou darovala klariskám. Zväčšili sa tak kláštorné záhrady s ovocnými stromami, ktoré klarisky využívali na oddych. V roku 1661 sa stala abatišou kláštora Mária Klára (1620 - 1685), dcéra Žigmunda Forgáča (Duchoňová 2012, 24-26).

Ďalšou známou postavou bola Margita Forgáčová (1726 - 1750), blízka príbuzná spomínanej Agneše. Jej otec bol Ján Forgáč, pravnuk Žigmunda Forgáča, ktorý bol královským radcom a novohradským županom. V roku 1750 namaloval jej posmrtný portrét nizozemský maliar Karol Wilhelm Brandt žijúci v Trnave. Portrét sa dnes nachádza v hradnom múzeu Červený Kameň (Varsík 1975, 9-29).

Na prelome 16. a 17. storočia naše územie poznačili stavovské povstania, turecká vojna, rýchly nástup reformácie, ako aj úpadok reholných inštitúcií spojených so sekularizáciou ich majetku. Nepokojom odolali len kláštory klarisiek v Bratislave a v Trnave, lebo sa nachádzali daleko od osmanskej línie. Preto sa v roku 1556 uchýlili ku klariskám do Trnavy begínky a klarisky z mesta Sarospatak (v dnešnom Mad’arsku), ktoré obsadili protestantskí povstalci. Kláštor a kostol v Trnave sa však nachádzali v zlom stave, o čom svedčia záznamy z roku 1615 a 1619, ked’ boli klariskám odpustené poplatky „adstructuram ruinosi sui claustri“. Na obnovu budov získali klarisky prostriedky vd’aka donačným aktivitám srcibiskupa Petra Pazmáňa, no už 7. septembra 1619 boli nútené utiect’ pred vojskami Gabriela Bethlena do mesta Bécsújhely, v súčasnosti Wiener Neustadt v Dolnom Rakúsku. Žili tu v ustavičnom strachu, pokial'sa nad nimi nezlutovala vdova po Žigmundovi Ratkayovi Fruzina Pálfiová, ktorá im poskytla vlastný dom v Záhrebe. Počas troch rokov strávených v Chorvátsku sa ich mecenášom stal ctihodný Peter Gál. 7. marca 1621 sa prestahovali bližšie do mestečka Bruck. Do Trnavy sa vrátili až v roku 1622 a pokračovali v prestavbe (MOL, fond C39, LAD. D, fasc. 40).

$\mathrm{V}$ duchu reformných myšlienok sa po návrate z mesta Wiener Neustadt pustili klarisky do prestavby kostola a celého kláštorného komplexu, ktorú finančne podporoval kardinál Peter Pázmáň. Hlavným ciel’om prestavby bolo zabezpečit prísnejšie dodržiavanie klauzúry. Za tým účelom sa predelil aj kláštorný kostol. Na prízemí prístavby vznikli priestory na komunikáciu smerom 
z kostola - vnútorné parlatórium, na poschodí zasa chór mníšok - oratórium, ktoré bolo súčastou klauzúry a od kostola ho delila stena so zamrežovaným oknom, cez ktoré obyvatelky kláštora zvonka nevidené, počúvali celebrujúceho kňaza (Duchoňová 2012, 8).

Prestavby kostola i kláštornej budovy narúšali vojnové taženia Juraja I. Rákociho v roku 1644, ked' boli klarisky znova nútené mesto opustit a uchýlili sa do mesta Kismarton v Rakúsku. Po návrate ešte $\mathrm{v}$ tom istom roku dali obnovit budovu kláštora a vytiahnut jeho múry na úroveň druhého poschodia. K pôvodnej budove dali postavit nové krídlo, ktoré vtiahlo predĺženú lod' kostola s vežou a vytvorilo základ pre nové západné nádvorie kláštora. No v roku 1645 boli opät nútené uchýlit sa do Rohožníka. Po návrate našli kláštor a kostol značne poškodený, preto žiadali v roku 1650 finančnú dotáciu od panovníka „pro restaurando templi choro modo in dies ruinam minante". V roku 1655 bolo pristavené d’alšie krídlo západného nádvoria, ktoré pohltilo pôvodne samostatný gotický dom. Vnútorné priestory kláštora museli tiež zodpovedat regule rádu (Oriško 1978, 89).

Ďalší stavebný vývoj kláštora bol pozastavený, pretože v roku 1683 vošiel do mesta so svojím vojskom Imrich Tököly a klarisky boli znovu nútené opustit kláštor. Odišli do Brna a v Trnave zostali len choré sestry so svojimi opatrovatel'kami. 8. augusta 1683 zasiahol kláštor rozsiahly požiar. Král' Leopold oslobodil majetky mníšok a ich poddaných od platenia daní a iných poplatkov, aby mohli financovat’ opravy; naspät sa vrátili až v roku 1685. Vdaka finančnej podpore arcibiskupa Juraja Séčéniho dali v roku 1694 opravit kláštor a obnovili výzdobu kostola (Čambál 2010, 101-102).

Kláštory klarisiek podporovali prestíž a ekonomické záujmy uhorských šlachtických rodov a vd’aka tejto skutočnosti získali určitý dynastický charakter, ktorý im zabezpečoval pravidelný „prísun“ rádového dorastu a finančných prostriedkov v podobe vena.

Základom hmotného zabezpečenia kláštorov klarisiek v Bratislave, Trnave a Budíne boli stredoveké donácie a nehnutel’nosti zaniknutých ženských kláštorov, ktoré im na začiatku 17. storočia darovali uhorskí panovníci. Majetky klarisiek predstavovali rozsiahle feudálne panstvá, ktoré sa delili na niekolko správnych celkov, na takzvané provizoriáty (MOL, fond C39, LAD. D, fasc. 40).

Do roku 1721 spravovali klarisky svoj majetok pod formálnym dozorom Mariánskej provincie františkánov. Vedenie provincie muselo schválit predaj nehnutelností, stavebné úpravy a s nimi súvisiace rozpočty a pravdepodobne aj investovanie kapitálu. Abatiše menovali právnych zástupcov svojich kláštorov, prijímali správcov a vyšších úradníkov na jednotlivé panstvá, vydávali pokyny a nariadenia, kontrolovali vedenie účtov. (ŠA Bratislava, fond MPF, 93a).

Uhorské klarisky, podobne ako iné stredoveké kontemplatívne rády, realizovali reformu v ranom novoveku pokusom o fixáciu stredovekých ideálov a striktnejším dodržiavaním rádovej regule. Pôvodné štatúty sa stali prostriedkom, pomocou ktorého sa chceli vymedzit’ voči novovznikajúcim reholným spoločenstvám a zachovat si svoju identitu. Regula rádu bola normatívnym dokumentom, obrazom ideálneho a očakávaného spôsobu života v kláštore; napriek svojmu normatívnemu charakteru bola často prepisovaná, upravovaná a modifikovaná podla lokálnych a dobových okolností. ${ }^{5}$

Postavenie každej mníšky predurčoval jej pôvod a výška vena, dížka pobytu v kláštore a v neposlednom rade aj jej ambície a schopnosti. Predstavenou kláštora bola abatiša, ktorá zodpovedala za náboženský život rehol’nej komunity a reprezentovala kláštor vo vztahoch s vonkajším svetom. Jej funkcia sa spájala s významným spoločenským postavením a prestížou a ak jej predstavitelka mala vplyvné rodinné zázemie, mohla sa stat rovnocenným partnerom cirkevným a svetským autoritám (Kušniráková 2010, 139). Zástupkyňou abatiše bola priorka, ktorá sa starala predovšetkým

5 Regula rádu je v tomto príspevku interpretovaná podla Constitutiones spísaných pre bratislavský a trnavský kláštor klarisiek v roku 1663. Pozri ŠA Bratislava, fond MPF, LAD. 30, Extra ordinem, n. 1. 
o majetkové a finančné záležitosti. Poradným zborom vedenia kláštora boli volené a večné diskrétky, ktoré spolurozhodovali najmä o prijatí noviciek a o spravovaní kláštorného majetku. Prestížne postavenie $\mathrm{v}$ reholnej komunite patrilo aj klariskám, ktoré dozerali na dodržiavanie klauzúry ${ }^{6}$ a vychovávali rádový dorast ${ }^{7}$. Uvedené posty zvyčajne získali staršie a skúsenejšie mnišky, ktoré sa považovali za odolnejšie voči lákadlám vonkajšieho sveta. Každodenný chod kláštora zabezpečovali šafárky, správkyne vínnych pivníc, nemecké a madarské sekretárky, opatrovatel'ky chorých a kuchárky (Kušniráková 2010, 139).

Tridentský koncil v snahe zabránit dedičnej držbe kláštorných funkcií a systému komendátorov nariadil trojročné funkčné obdobie a tajnú volbu predstavenstva kláštorov (Duchoňová 2012, 8). Kandidátka na post abatiše musela mat minimálne 40 rokov a aspoň osem rokov musela strávit $\mathrm{v}$ ráde ako mníška s večnými slubmi. Ak delegát Mariánskej provincie františkánov nesúhlasil s jej kandidatúrou, mohol navrhnút novú kandidátku. Vedenie kláštora volili všetky mnišky, ktorým od zloženia večných slubov uplynuli minimálne štyri roky. Z volby boli vylúčené laické sestry a novicky. Oprávnené voličky odovzdávali svoj hlas ústne vyslaným delegátom provincie a ostrihomského arcibiskupa, ktorí sa počas volieb nachádzali v parlatóriu. Zvolená abatiša a priorka museli získat viac ako polovicu všetkých hlasov, diskrétkami sa stali mniśky, ktoré získali najviac hlasov ${ }^{8}$ (ŠA, fond MPF, LAD. 29, fasc. 10, n. 6).

Od 12. storočia sa novým fenoménom stali laické sestry, ktoré tvorili približne jednu štvrtinu z celkového počtu klarisiek v jednotlivých kláštoroch. Pochádzali z nižších spoločenských vrstiev ako chórové sestry a kláštor od nich nepožadoval vstupné veno. Od chórových sestier sa odlišovali už na prvý pohlad odevom a nižším štandardom ubytovania. Laické sestry nemohli volit a byt’ volené. Ich účast na náboženskom živote komunity bola zredukovaná, aby mohli viac času venovat’ manuálnej práci. Ich práca sa považovala za menejcennú, väčšiu úctu a vážnost' mala „opus deti“ chórových sestier, ktorých práca mala viac duchovný ako materiálny význam a kláštor $\mathrm{z}$ nej nemal žiadny hmotný alebo finančný prospech. Počas zimného obdobia spávali laické sestry v spoločnom dormitóriu, lebo v ich celách chýbali pece na vykurovanie (Kušniráková 2010, 140). Regula rádu predpisovala klariskám skromné výbavy ciel, aby sa nerozptylovali materiálnymi vecami a lahšie sa sústredili na službu Bohu. Abatiša bola povinná pravidelne kontrolovat’ cely a odstránit z nich všetko, čo by odporovalo chudobnému spôsobu života. V každej cele sa okrem postele, klačadla a kríža nachádzalo niekol'ko stolov a stolíkov, kanapy, kreslá, stoličky, skrine, truhlice a rôzne skrinky. Najsolventnejšie mníšky si nechali na vlastné náklady vybudovat elegantné pece na vykurovanie. Nábytok v celách formálne patril kláštoru, zaobstarali si ho však mnísy s pomocou svojich rodín a kláštor ním nemohol disponovat bez ich súhlasu (MOL, fond C103, 32d).

Rádový odev tmavej hnedej farby a nakrátko ostrihané vlasy symbolizovali definitívny odchod klarisiek zo svetského života a príslušnost' k reholnej komunite. Uhorské kláštory v ranom novoveku už nevyžadovali, aby bol mnišsky odev zhotovený z drsného materiálu. Mníšky zo zámožnejších rodín si mohli zadovážit látky na kvalitnejšie ošatenie, na čo si prispievali $z$ vlastných prostriedkov. V Trnave musela abatiša v priebehu svojho trojročného funkčného obdobia zabezpečit každej mníške kompletnú sadu nového ošatenia a každoročne dve šnurovačky a mušelín na čierny závoj. Zimné ošatenie - povolené boli aj kožuchy - si mníšky museli zabezpečit’

\footnotetext{
6 Na dodržiavanie klauzúry dozerali mníšky, ktoré slúžili na rote, pri bráne a sestry načúvajúce.

7 Chovankyne kláštora viedla majsterka detí, výchovou noviciek bola poverená majsterka noviciek, za formovanie mladých mníšok do 24 rokov zodpovedala majsterka mladých mníšok. Tieto funkcie sa podla počtu zverenkýň mohli kumulovat', prípadne jednotlivé majsterky mohli mat’ svoje asistentky.

8 Dve až štyri volené diskrétky sa rovnako ako abatiša a priorka volili na tri roky. Večné diskrétky sa volili na doživotie; zvyčajne túto funkciu zastávali tri až štyri mníšky.
} 
na vlastné náklady. Konvent ho poskytol len tým, ktoré nemali rodičov alebo iných dobrodincov (MOL, fond C39, LAD. D, fasc. 40).

Pri spoločnom stolovaní v refektári sa dôraz kládol na zásadu, že okrem tela má dostávat pokrm aj duša, preto sa počas stolovania nahlas čítalo z náboženskej literatúry. Počas stolovania sa mniśky mali vyhýbat zbytočnému klebeteniu a čas strávený v refektári nemali neúmerne predlžovat'. Pôst bol predpísaný štyrikrát v týždni a základ jeho jedálneho lístka tvorili ryby, raky a vajcia. Ako dezert sa podávalo ovocie z kláštornej záhrady (MOL, fond C103m 32d).

Každodenný život v kláštore klarisiek predstavoval opakovaný cyklus modlitieb, práce a kontemplácie. Kontemplatívny charakter rádu vyžadoval dodržiavanie kanonických hodiniek, od ktorých sa následne odvíjal režim celého dňa. V čase medzi pobožnostami si mníšky plnili povinnosti, ktoré im vyplývali z ich úradu alebo funkcie. Čast’ dňa trávili spoločne a venovali sa šitiu habitov alebo ručným prácam. Zhotovené výrobky darovali svojim patrónom a dobrodincom alebo nimi zdobili kláštorný kostol, či kostoly na kláštorných majetkoch. Vo volnom čase sa mohli venovat' svojim zálubám, najmä malovaniu a hre na hudobné nástroje (Duchoňová 2012, 15).

Z roku 1633 pochádza nariadenie pápeža Urbana IV. vydané pre trnavský kláštor o vykonávaní liturgických hodiniek. Rukopisy liturgických piesní, ktoré spieval svätý František a učebnica zborovej hudby obsahovali základy najstaršej formy chórového spevu. Chórové sestry sa venovali spevu liturgických piesní v sprievode hudobných nástrojov. Podla archívnych dokumentov sa v kláštore už v roku 1715 nachádzal jeden organ, ale aj pät trombónov, 2 medené tympany a klavichord. Okrem toho tu pôsobili majsterky ako učitelky hudby, spevu, hry na organ pre dievčatká od 4 až 6 rokov, ktoré dávali do kláštora na výchovu rodiny zo vznešených rodov (Mészárosová 2005, 163-175). Dievčatá sa naučili pokore, hre na hudobné nástroje a chórovému spevu. Čast’ chovankýň sa mohla neskôr vrátit’ do svetského života a vydat’ sa, no väčšina zostala a stala sa mníškami (Kušniráková 2011, 28-32).

\section{Klarisky v Bratislave}

Bývalý klariský kláštor je najstaršou z budov Univerzity Komenského v Bratislave. Kláštor a kostol klarisiek sa nachádza v historickom centre mesta ako neprehliadnutelný masívny blok historických budov, ktorý vznikol na mieste najstaršieho kláštora v meste.

Pôvodne na tomto mieste stál kláštor cisterciánok. O ich príchode sa nezachovali presné údaje, ale predpokladá sa, že sa tu usadili bezprostredne pred rokom 1235, lebo v tomto roku generálna kapitula v Citeaux na pápežov príhovor inkorporovala „Abbatia de Posonio“, teda opátstvo cisterciánok v Bratislave. O ich pôsobení vieme velmi málo a nie je jasné ani to, kedy opustili Bratislavu (približne po tridsiatich rokoch). V listine Ondreja III., ktorou daroval klariskám kláštor cisterciánok, sa spomína, že budovy sú prázdne už dvadsat rokov; napriek viacerým výzvam cisterciánskeho rádu, aby budovy využívali pre kláštor a jeho statky, prešli do majetku panovníka, ktorý nimi mohol volne disponovat' (Kostka 1976, 29).

Iniciatíva na založenie klariskej komunity v Bratislave vznikla začiatkom prvého decénia 13. storočia medzi miestnymi ženami. Na ich podnet provinciál františkánskeho rádu Barnabáš v Ríme viackrát tlmočil žiadost’ o povolenie usadit rád v Bratislave. Pápež Bonifác VIII. udelil 12. 9. 1297 súhlas a poveril kardinála Mathea, aby jeho rozhodnutie oznámil provinciálovi do Bratislavy s tým, že pri organizovaní činnosti novozaloženého kláštora majú pomáhat reholníčky, ktoré dobre poznajú predpisy a spôsob života klariského rádu. Treba im zabezpečit zaopatrenie, ubytovanie zodpovedajúce ich kánonom a s ich usadením musí súhlasit aj bratislavská kapitula. Dušpastierskou činnostou a vizitáciou boli poverení františkáni (Kušniráková 2011, 132). 
V októbri boli prestahované minimálne štyri až šest’ sestier (pravdepodobne $\mathrm{z}$ Trnavy) do Bratislavy a zverili im úlohu životom naplnit predpis podla reguly v novej komunite. Provinciál intervenoval aj u panovníka ako hlavného patróna, aby pre klarisky získal bývalý cisterciánsky kláštor a všetky k nemu patriace stavby. Ondrej III. vydal 26.10.1297 privilégium, v ktorom ako královskú donáciu daroval všetky uvedené nehnutelnosti a majetky klariskám (... ad dictum claustrum religiosae Dominae eiusdem ordinis redire neglexerint...). V dalšej listine z toho istého dňa potvrdzuje akt darovania (... fundo, seu curia vel area. per eosdem cives Pasonienses, donate seu collata) a berie ich pod svoju ochranu (... et in nostram protectionem cum procuratore et rebus ad se pertinentibus modo predictio assemptas...). Ešte $\mathrm{v}$ tom istom roku prikázal bratislavskému richtárovi a magistrátu mesta, aby ochránili vlastníctvo všetkých pozemkov a statkov klarisiek, ktorý im pri založení kláštora daroval. Patrónkou kostola bola sv. Mária Magdaléna (ŠA Bratislava, fond MPF, LAD. 29, fasc. 3, n. 7). Budovu, ktorá bola dlhšiu dobu opustená a značne poškodená, opravili a prispôsobili novým potrebám.

O prvých rokoch života reholníc nemáme vela údajov, ale vieme, že pod vedením opátky žili svoj kontemplatívny život v pravidelnej modlitbe, dobrovolnej chudobe a v prísnej klauzúre. Kláštor mohli opustit len výnimočne z dôvodu plnenia slubu, v záujme viery a rádu, napr. pri zakladaní nového kláštora a v prípade ohrozenia života.

Kedže získali aj statky, ktoré mali kryt náklady na obživu a ostatné existenčné potreby, bratislavský prepošt a kapitula $\mathrm{z}$ ich majetkov žiadali desiatky. Klarisky sa v roku 1310 obrátili na vyslanca pápeža Klementa V., kardinála Montefiore Gentilisa, aby ich od platenia desiatkov oslobodil. Ešte $\mathrm{v}$ tom istom roku Gentilis vydal pre reholný rád privilégium, podla ktorého neboli nikomu povinné platit' desiatky zo svojich statkov. Benedikt XII. vydal 8. 1. 1335 rozhodnutie, ktorým všetky klariské kláštory - teda i bratislavský - oslobodil od platenia desiatkov a akýchkolvek bremien cirkevným alebo svetským osobám, a to tak na súčasné, ako i budúce statky a majetky. Král Ludovít I. sa klarisiek tiež zastal v roku 1345 v súvislosti so sporom o vinohrad a ubezpečil ich, že sa kedykolvek môžu obrátit na neho alebo jeho matku. Prvá predstavená je známa z roku 1382 pod menom Kunigunda. Zo 14. a 15. storočia sa zachovali sporadické správy o klauzúrach $\mathrm{v}$ súvislosti s darmi v podobe vinohradov, lúk alebo finančnej hotovosti. Král Žigmund v roku 1392 prijal klarisky, ich majetky a poddaných do svojej zvláštnej priazne (privilegium protectionale) a královskej ochrany. V listine z 28. marca 1421 potvrdzuje znovu všetky ich privilégiá a práva. Okolo roku 1433 sa začali zbierat peniaze na prestavbu kostola. V tomto období poskytli útočisko aj klariskám z Trnavy, ktoré utiekli pred husitmi a až do roku 1435 sa zdržiavali v bratislavskom kláštore (ŠA Bratislava, fond MPF, LAD. 29, fasc. 4).

V roku 1515 vypukol v královskej kuchyni požiar, ktorý sa rýchlo rozšíril a zhorela väčšia čast' mesta aj s klariským kláštorom. Kostol bol síce ušetrený, ale rehol'nice museli žit' vo vel’mi poškodenej budove a vo velkej biede. Požiadali o pomoc krála, ktorý im z výnosov mýta poskytol tisíc zlatých na stavebné náklady. Sumou 150 zlatých prispeli aj meštania Bratislavy. Na živobytie dostávali od panovníka almužnu - štyri florény týždenne. Ešte nestačili dokončit obnovu kláštora, ked'v roku 1529 Turci tiahli na Viedeň a klarisky pred nimi utiekli do bezpečnejšej Trnavy. Mesto do ich budovy umiestnilo rád sv. Antona, ktorý sa venoval ošetrovaniu starých a chorých, lebo ich kostol so špitálom spolu s predmestskými kostolmi sv. Vavrinca, Michala a Mikuláša pred príchodom Turkov zbúrali. Ferdinand I. v roku 1530 píše mestskej rade, aby umožnila mníškam návrat do kláštora a aby si neprivlastňovala ich príjmy. Do Bratislavy sa vrátila iba predstavená kláštora, ktorá pred smrtou súhlasila s tým, aby sa kláštor a všetky jeho príjmy použili pre potreby mestského špitála. S tým 25. augusta 1540 súhlasil aj panovník (ŠA Bratislava, fond MPF, LAD. 29, fasc. 1-13).

Klarisky v Starom Budíne - ústrednom kláštore rádu v Uhorsku - museli v roku 1541 pri obliehaní Budína Turkami svoj kláštor opustił a utiekli do Bratislavy. Spočiatku bývali v prenajatom 
dome, ale usilovali sa o znovu získanie klariského kláštora. Mesto sa odvolávalo na súhlas panovníka, ale kedže išlo o cirkevnú budovu, so zmenou funkcie budovy museli súhlasit aj cirkevní nadriadení. Tento súhlas chýbal, preto súd 1. mája 1543 zaviazal magistrát Bratislavy k prestahovaniu špitála a vráteniu kláštora klariskám. Kedže sa mesto zdráhalo budovu odovzdat', nariadil Ferdinand o rok neskôr vykonanie rozsudku bez možnosti odvolania. Klarisky 10. decembra 1577 bývali spät v kláštore. Na ich živobytie slúžili pozemky v pätnástich obciach bratislavskej stolice, ktoré pôvodne vlastnili starobudínske klarisky. Panovník oslobodil ich vozy s potravinami od platenia tridsiatkového mýta a o rok neskôr, v roku 1545 opätovne nariadil, aby im bratislavský tridsiatkový úrad týždenne vyplácal štyri florény ako almužnu. Arcibiskup - aj vo funkcii miestodržitela - oslobodil ich statky aj od povinnosti ubytovávat' vojakov (Schövitzky 1886, 13-52).

V roku 1581 mníšky, ktoré žili v skromných, stiesnených podmienkach, žiadali mesto, aby im prepustilo volnú parcelu na rohu Klariskej ulice a ulice Na vŕšku. Kedže pri poškodenej kláštornej budove nemali záhradu, žiadali od mesta aj dalšiu parcelu od ulice Na vŕšku smerom k mestským múrom. Mesto ich žiadosti vyhovelo. K zväčšeniu kláštora, o ktorom sa píše v dohode medzi mestom a abatišou Ilonou, vtedy nedošlo. O niekolko rokov neskôr, v roku 1590, postihlo mesto zemetrasenie a kláštorná budova sa začala rozpadávat'. Nestihli sa urobit ani najnutnejšie opravy, ked’ ešte v tom istom roku na Zámočníckej ulici pri Michalskej veži vznikol požiar a takmer celé mesto $s$ kostolom a kláštorom klarisiek lahli popolom. Podoba, ktorú získal obnovený kostol po tomto požiari, sa zachovala dodnes. Kláštornú budovu opravili len núdzovo (ŠA Bratislava, fond MPF, LAD 29, fasc. 1-13).

Rudolf I. na obnovu budov $\mathrm{v}$ roku 1600 venoval majetky kláštora premonštrátok v Somlyóvásárhelyi a od tých čias bratislavská opátka niesla titul „Sanctimonialum de Veteri Buda et de Vásárhelyi abbatissa“" (Karácsony 1923, 472).

V roku 1605 sa protihabsburskí povstalci blížili k Bratislave, preto reholnice utiekli do Grazu a odtial' o rok neskôr do Viedne, kde ich prijali do klariského kláštora a tu sa zdržali až do februára 1607. V tom čase už viedenské klarisky žili podla prísnejšej reformovanej reguly, preto pred odchodom prosili predstavenú, aby umožnila aspoň trom mníškam prejst’ do Bratislavy, aby aj tam zaviedli reformovaný spôsob života. O pár mesiacov neskôr sa tri klarisky z Viedne stali postupne opátkami, zmenili vnútorný život kláštora a vykonali aj nutné opravy na budovách. Reformy sa týkali prísnejšej klauzúry, disciplíny a chórových ceremónií. Kým predtým predstavenú volili do funkcie doživotne, podla nových pravidiel ju už mohli volit len na tri roky. Podla buly Klementa VIII. z roku 1595 mohli predstavené všetkých rádov zastávat svoju funkciu opakovane aj viac volebných období (Szyllaba 1944, 87).

V rokoch 1610 - 1612 reholnice žiadali Mateja II., aby pomohol pri oprave a rozšírení kláštora. Chceli od mesta odkúpit’ susedné meštianske domy. Napriek královskému súhlasu to mesto odmietlo a trvalo až do roku 1615, kým sa im po dlhých rokovaniach podarilo za 600 florénov získat’ susedné domy na plánovanú prestavbu kláštora (ŠA Bratislava, fond MPF, 930a).

Začiatkom 17. storočia sa počet obyvateliek kláštora zvýšil. Dominikánky z Margitinho ostrova utiekli ešte v roku 1541, ked' Turci obsadili Budín. Po pobyte v iných mestách sa v roku 1567 usadili v dominikánskom kláštore v Trnave. V roku 1615 pápež Pavol V. povolil ostrihomskému arcibiskupovi, aby mníšky prestahoval a kláštornú budovu využil pre potreby jezuitského kolégia. Mníšky načas bývali v klariskom kláštore v Trnave a v roku 1618 sa prestahovali do bratislavského kláštora. Panovník Matej II. listinou preniesol všetky práva a majetky dominikánok na kláštor klarisiek. Dominikánky okrem svojich cenností a kódexov priniesli aj relikvie sv. Margity, ktoré umiestnili v sakristii kostola, čím sa zvýšil význam celého kláštora a jeho návštevu mali v programe mnohí pútnici z domova i zo sveta. $Z$ desiatich dominikánok dve dožili v pôvodnom rúchu podla dominikánskych regúl, ostatné prestúpili ku klariskám, prijali ich rúcho a spôsob života (Némethy 1884). 
Pred bližiacimi sa bethlenovskými vojskami v roku 1619 sestry utiekli do Viedne, kde sa ubytovali v jednom meštianskom dome a zotrvali tam štyri roky. Manželka Ferdinanda II. Eleonóra darovala štrnástim nemeckým sestrám z Bratislavy prázdny kláštor pri kostole sv. Mikuláša, a tak sa bratislavské reholnice stali zakladatel'kami druhého klariského kláštora vo Viedni. V tomto období prišli sestry o viaceré majetky okrem iných aj o majer so záhradou na Panenskej ulici. Služobníctvo s hospodárskymi zvieratami nebolo kam umiestnit', preto žili v lete i v zime na nádvorí kláštora. Až v roku 1627 intervenoval u mesta palatín Mikuláš Esterházy, aby mníškam opät dovolili na uprázdnenom mieste ich pôvodných hospodárskych stavieb postavit potrebné budovy, za ktoré by mestu platili nájom. Mesto síce súhlasilo, ale v zmluve vymedzilo velmi prísne podmienky. Otázka umiestnenia čelade zvierat sa týmto vyriešila, ale kláštorná budova bola čoraz nevyhovujúcejšia. Mecénom prestavby, opravy kláštorov klarisiek v Trnave, v Nových Zámkoch a v Bratislave bol ostrihomský arcibiskup Peter Pázmáň a kedže bol aj protektorom bratislavských klarisiek, poznal kritický stav kláštornej budovy. Na jej prestavbu ponúkol financie z vlastných zdrojov. Prestavba sa zahájila v roku 1633; počas nej bolo treba reholnice umiestnit do náhradných priestorov (MOL, fond C39, LAD. D, fasc. 40). Stavebné práce trvali namiesto dvoch až šest rokov a kláštornú budovu odovzdali do užívania začiatkom roka 1640. Svedčí o tom aj nápis nad bránou kláštora, podla ktorého tento rozpadávajúci sa kláštor dal rozobrat kardinál Peter Pázmáň, ostrihomský arcibiskup. Dal ho postavit’ od základov až po strechu, ale skôr, než mohol dielo dokončit, zomrel 19. marca 1637. Imrich Lósy, ostrihomský arcibiskup ho štastne dokončil, požehnal a v roku 1640 sem uviedol panny zasvätené Bohu podla reguly sv. Kláry. Aj ked’sa sestry do kláštora nastahovali, stavebné práce na parcele tzv. Stecherovho domu, o ktorý sa kláštor u mesta uchádzal už od roku 1613, ešte pokračovali; boj o dom trval aj po intervencii panovníka, palatína a iných priaznivcov až do roku 1637. Kvôli pokračujúcim stavebným prácam na tejto parcele mesto odpustilo kláštoru platenie nájmu ešte aj v rokoch 1641 - 1643. Kláštorná budova s neskoršími zásahmi v interiéri sa v podobe tejto prestavby zachovala dodnes (ŠA Bratislava, fond MPF, LAD. 29, fasc. 1-13).

V roku 1645 čast’ reholníc odišla do Györu pred blížiacimi sa vojskami, ktoré tiahli proti Ferdinandovi III. V tom istom roku požiadal gróf Gašpar Draškovič, fundátor znovu založeného klariského kláštora $\mathrm{v}$ Záhrebe generálneho komisára rádu o súhlas $\mathrm{k}$ preloženiu desiatich až jedenástich sestier z bratislavského do záhrebského kláštora. Bratislavské klarisky sa tam vybrali pod vedením svojho františkánskeho spovedníka a v roku 1649 založili klariský kláštor v Záhrebe (Némethy 1884).

Ked’ sa Turci v roku 1663 blížili k Bratislave, mníšky utiekli do Güssingu, kde sa zdržali trinást’ mesiacov. Pri morovej epidémii v meste v roku 1679 za tri týždne zomrelo trinást' sestier, ostatné sa prestahovali do blízkeho domu palatína Pavla Esterházyho. Pre obete moru vytvorili separovanú kryptu (Karácsony 1923, 472).

Koncom 17. storočia sa bratislavský konvent stal ústredím klariského rádu v Uhorsku. V tom čase sa finančná situácia kláštora - z príjmov z poddanských osád, z darov dobrodincov a $\mathrm{z}$ vien, ktoré priniesli so sebou kandidátky pri vstupe do kláštora - skonsolidovala natolko, že jednotlivcom i mestu mohli poskytovat' aj pôžičky (Kósa 1768, Ms 830).

Zemetrasenie v roku 1700 poškodilo vežu kostola; o dva roky ju vtedajšia opátka nechala opravit', o čom svedčí nápis na nej (Kostka 1976, 63).

Mestská komisia 10. júna 1708 robila obhliadku kláštora. Okrem toho, že preskúmala zvony a nariadila opravit ich uvol’nené skrutky, rozhodla, že pre kláštornú kúpelňu a práčovňu treba vyvŕtat’ studňu s pumpou. Ďalšia komisia bola v kláštore o štyri roky, ked’ z kláštorných aj vonkajších kanálov vnikala do pivnice voda. Staré kanály zasypali a smerom k hradbovým múrom vykopali nové (Kostka 1976, 67). 
Ďalšia morová epidémia zasiahla mesto v roku 1713. Vtedy niekolko sestier ostalo v kláštore a 27 ich odišlo do Sládkovičova na kláštorný majetok. Zo Sládkovičova sa pred zimou presunuli do Trnavy, kde bývali v súkromnom dome. Počas epidémie obyvatel’stvo mesta požiadalo konvent o zapožičanie relikvií sv. Margity, ktoré v slávnostnom sprievode prenášali okolo mesta ako ochranu proti moru. Devät klarisiek sa v novembri 1714 prestahovalo do Budína, aby tam znovu založili klariský kláštor. Ostávajúce sestry sa s nimi podelili o majetky, vzácnosti a relikvie kláštora (MOL, fond C103, 32d).

Františkánske definitórium v roku 1721 vyhlásilo, že provincia, ako aj jej členovia sa v zmysle pápežských ustanovení zriekajú zodpovednosti za hospodárenie klariských kláštorov a vymedzilo podmienky poskytovania duchovných služieb klariskám a ich bratislavskému kostolu. Predstavená sa zaviazala za tieto služby plnit dohodnuté záväzky (ŠA Bratislava, fond MPF, fond MPF, LAD. 29 , fasc. 10, n.5).

V roku 1764 v kláštore obnovili a zväčšili priestory na pochovávanie, čim vznikli tri krypty: jedna pod kostolom, rozdelená na dve časti, a dve pod budovou. Pod kostolom sa mohli pochovávat’ aj svetské osoby, pod budovou iba reholnice (ŠA Bratislava, fond MPF, LAD. 29, fasc. 1-13).

\section{Zrušenie rádu klarisiek v Uhorsku}

Už od polovice 18. storočia možno pozorovat snahy o reformu cirkevných rádov. Podporovala ich aj Mária Terézia v rámci úsilia vybudovat štátno-cirkevnú ríšu. Postupne sa rôznymi nariadeniami obmedzoval počet kláštorov, reholníkom sa zakazovalo skladat slub do 24. roku života, určovalo sa, aký majetok môžu priniest' pri vstupe do kláštora a ako sa má naložit’ s ich dedičstvom (Mészárosová 2004/2005, 22).

V roku 1770 nechala o každom kláštore vypracovat výkaz o osobách, ktoré sa tam zdržujú a o majetkových pomeroch kláštora. Štát na základe týchto výkazov získal kompletný prehlad o všetkých kláštoroch na svojom území. Po jej smrti v realizácii jej programu pokračoval jej syn Jozef II. K právnej príprave zrušenia patrilo, že v januári 1781 úrady žiadali, aby kláštory predložili všetky svoje privilégiá a povolenia. Panovnícky dvor v marci zakázal všetkým kláštorom, aby udržiavali kontakty so svojimi predstavenými v zahraničí. Napriek tomu, že tento fakt vyvolal silný protest, pokračovalo sa v načatej ceste a 20. mája zakázali všetkým mužským a ženským rádom prijímanie nových členov (Mészárosová 2004/2005, 22).

Historiografia zväčša interpretuje rušenie kláštorov v čase panovania Jozefa II. na základe argumentácie stúpencov osvietenských názorov, že vzhladom na zbytočnost’ a neužitočnost kontemplatívnych rádov bolo rozhodnutie panovníka správne a oprávnené. Menej alebo vôbec sa spomínajú názory ich odporcov. Majú racionálny a logický základ. Odporcovia rušenia kláštorov klarisiek sa vo svojej argumentácii odvolávali na právo, tradície a uhorské zvyky. Podla ich názoru bola existencia kláštorov klarisiek garantovaná zákonnými článkami uhorského snemu podobne ako práva a slobody protestantov, ktorí najviac žiadajú ich zrušenie. Odmietali tvrdenia, že kontemplatívny spôsob života je v rozpore s vôlou ich zakladatelov a dobrodincov, čo oprávňuje panovníka k ich legálnemu zrušeniu. Uhorskí panovníci poznali spôsob ich života a svoje donácie nepodmieňovali dobročinnými alebo inými verejno-prospešnými aktivitami mníšok. $\mathrm{V}$ argumentácii pokračovali tvrdením, že klariskám patria rovnaké práva a výsady ako ostatným osobám urodzeného pôvodu, ktorým na základe zákonných článkov 2 a 3 z roku 1723 nemožno odňat majetok ani kvôli dlhom. Klarisky nevymreli, preto sa im majetok nemôže odobrat tak ako inej urodzenej rodine, ktorá má svojich potomkov (Kušniráková 2010, 144).

Napriek nesúhlasnému postoju cirkevných elít, ktorý podporila aj Miestodržitel’ská rada, panovník ponechal v platnosti dekrét z 28. januára 1782 o zrušení kláštorov klarisiek a iných rádov 
a 8. februára vydal další dekrét, ktorým upravil okolnosti rušenia jednotlivých kláštorov, spôsob prevzatia ich majetku a otázku budúceho zaopatrenia prepustených reholníkov ${ }^{9}$ (ŠA Bratislava, fond MPF, 930a).

Rozhodnutie panovníka o zrušení kláštorov klarisiek oznámili mníškam v jednotlivých kláštoroch vyslaní královskí komisári. Nariadenie Jozefa II. bratislavským klariskám vládni komisári prečítali 2. 3.1782 (ŠA Bratislava, LAD.29, fasc 1-13). V trnavskom kláštore královská komisia na čele s podžupanom Michalom Ambrom vyhlásila 18. apríla 1782 príkaz, proti ktorému neexistovalo odvolanie (Mészárosová 2012, 17).

Po prečítaní dekrétu o zrušení kláštora mohli sestry zostat nasledujúcich pät mesiacov, počas ktorých sa mali rozhodnút, či vstúpia do iného rádu alebo sa vrátia do svetského života. Niektoré vstúpili k alžbetínkam a uršulínkam, ostatné sa prestahovali do súkromných domov ${ }^{10}$ (Kušniráková 2010, 145). Vzácne predmety z kláštora umiestnili v sklade královského depozitného úradu pre cirkevné predmety (Königliches Kirchengerätschaften Depositenamt); ich čast’ rozpredali 3. 5. 1784 na verejnej dražbe. Do skladu odviezli aj 53 rukopisných kódexov a tlačí zachytených v aboličnom súpise bratislavského kláštora (MOL, fond C39, LAD. D, fasc. 40).

V rámci kasácie opustilo kláštor 42 reholníc: 2 opátky, 28 chórových sestier, 10 laičiek a 2 novicky. Ich odchodom po 500 rokoch definitívne ukončil klariský konvent v Bratislave svoju činnost'. Pre kláštornú budovu, ktorá bola relatívne v dobrom stave, dva roky hladali vhodné využitie. V roku 1784 ju odovzdali Královskej akadémii, ktorú prestahovali z Trnavy do Bratislavy (ŠA Bratislava, fond MPF, LAD. 29, fasc. 1-13).

Rád klarisiek pôsobil v bývalom Uhorsku takmer pätsto rokov. O význame tejto rehole svedčí aj skutočnost', že jej príslušníčky požívali mimoriadnu ochranu uhorských panovníkov.

Osobitnú pozornost' si zasluhuje kostol klarisiek. História miesta, na ktorom stál pôvodný kostol cisterciánok, siaha do čias pred naším letopočtom. Archeologický prieskum vykonaný v roku 2007 potvrdil, že tu už v 1. storočí pred Kr. existovalo keltské oppidum s opevnenou akropolou (Bagin - Krajči 1988, 29).

Klarisky čoskoro po nadobudnutí zničenej kláštornej budovy začali stavbu opravovat a súčasne začali aj s výstavbou kostola zasväteného Povýšeniu svätého Kríža. Základ stavby kostola tvorili obvodové múry postavené začiatkom 14 . storočia. V jeho druhej polovici došlo k predľženiu lode o jedno klenbové pole; vystaval sa triumfálny oblúk a presbytérium. Okolo roku 1370 bola táto stavebná etapa zavŕšená a pristúpilo sa k zaklenutiu lode krí̌ovou klenbou. Do nasledujúceho storočia sa pretiahla výstavba architektonicky najhodnotnejšej časti kostola - veže. Nebola však postavená od základov, ale nadstavali ju na spevnené piliere juhozápadného nárožia chrámovej lode. Nielen svojím tvarom - v podobe pätbokého hranola, čo bolo pre gotické stavebné umenie zriedkavé - ale aj výtvarným stvárnením - predstavuje uvedený sloh klenot v dejinách architektúry na Slovensku. Trojetážová pätboká stavba svojou konštrukciou, tvarom, zvláštnym umiestnením a výzdobou patrí k unikátnym zjavom v dejinách stavebníctva na Slovensku. Pri jej plánovaní stavitelia istým spôsobom obišli nariadenie, podla ktorého kostoly žobravých rádov nesmeli mat' vežu. Tým, že je umiestnená na nároží lode kostola, nie je viditel’ná v pôdoryse a nevyrastá priamo zo základov stavby (Kostka 1988, 116).

9 Kronikár Mariánskej provincie františkánov si k tejto udalosti poznamenal: „Kedže sa nepodarilo obmäkčit srdce najjasnejšieho panovníka (Pán Boh vie, $z$ akého dôvodu) a priviest' ho $k$ súcitu, boli kamalduli aj klarisky vo všetkých provinciách $v$ Uhorsku a v pripojených krajinách zrušení, vyhnaní z kláštorov, ktoré plným právom vlastnili a uvrhnutí do toho najbiednejšieho života."

10 Na základe rozhodnutia Jozefa II. sa chórovým sestrám priznala doživotná renta 200 zlatých ročne a laickým sestrám 150 zlatých. Táto podpora však zdaleka nemohla pokryt všetky životné náklady bývalých klarisiek. 
Mnohé živelné pohromy (požiare, zemetrasenie) a historické udalosti značne ovplyvnili osudy oboch stavieb - kláštora i kostola. Nová etapa rozvoja kláštora a kostola nastala v 17. storočí vdaka spomínanému ostrihomskému arcibiskupovi Petrovi Pázmaňovi. Chrám slúžil klariskám bez väčších problémov, na veži sa však začali objavovat statické poruchy, ktoré zrejme spôsobilo zemetrasenie v roku 1700. Vtedajšia opátka kláštora Eva Barbora Balassová v roku 1702 nariadila rekonštrukciu veže, ktorá dostala zakončenie barokového cibulového tvaru. Okrem toho v priebehu 18. storočia kostol prešiel celkovou obmenou v duchu nastupujúceho rokoka. Interiér dostal iluzívnu výmalbu stien svätyne a stropu lode, ktorá dotvárala celkový umelecký dojem (Bagin Krajči 1988, 38).

Radikálnu zmenu využitia chrámových priestorov priniesli reformy cisára Jozefa II. potom, čo kláštor opustili posledné klarisky (1782). Do roku 1784 ostal kláštor s kostolom prázdny. Vtedy bola do objektov z Trnavy prestahovaná právnická akadémia, ktorá tu sídlila do roku 1851 . Od roku 1786 k nej pričlenili inú školskú ustanovizeň - katolícke gymnázium, ktoré v týchto priestoroch existovalo až do roku 1908. V druhej polovici 19. storočia veža dostala vzhlad, ktorý korešpondoval s gotickým výzorom kostola. Stavba veže však príliš zatažila nárožie lode, čo viedlo $\mathrm{k}$ jeho deštrukcii. Preto bolo potrebné postavit nový oporný pilier z traventínových kvádrov a tým nárožie staticky zabezpečit'. Ked’ v roku 1913 kostol opustili študenti, bol odsvätený a prestali sa $\mathrm{v}$ ňom konat bohoslužby. Od tých čias mal kostol rôzne využitie. Od roku 1914 sa spolu s kláštorom dostal do majetku mesta, ktoré ich dalo k dispozícii novoutvorenej Univerzitnej knižnici. Kostol v priebehu nasledujúcich rokov vykazoval vážne statické nedostatky, preto bol pre verejnost’ na dlhé roky zatvorený. Až v roku 1943 bol na naliehanie občanov Bratislavy vypracovaný plán jeho obnovy. Prevedené reštaurátorské práce však neboli velmi vydarené (Bagin - Krajči 1988, 42).

V roku 1964 mesto pridelilo kostol Galérii mesta Bratislavy. V súčasnosti sa interiér využíva na príležitostné umelecké výstavy a ako koncertná sieň.

S históriou komplexu kláštora a kostola klarisiek súvisí aj niekolko zaujímavostí. Jednou z najvzácnejších obyvateliek kláštora bola česká královná - vdova Žofia Bavorská. Po smrti svojho manžela, krála Václava IV. Luxemburského, sa v roku 1419 uchýlila do prešporského kláštora klarisiek. Pod ochranou svojho švagra uhorského krála Žigmunda Luxemburského tu žila až do svojej smrti v septembri 1425. V čase, ked kláštorná budova slúžila ako škola, študovalo tu niekol'ko význačných osobností, napr. mad’arský hudobný skladatel' Béla Bartók, či slovenský kňaz a vynálezca Jozef Murgaš.

\section{KLARISKY KAPUCÍNKY V SÚČASNOSTI NA SLOVENSKU}

V Kopernici ned’aleko Kremnice sa nad starým kostolom vypína moderná stavba kláštora klarisiek kapucínok, ktorú dal postavit’ a neskôr konsekroval banskobystrický biskup Rudolf Baláž. Ide o malé spoločenstvo pozostávajúce zo štyroch sestier. Pôsobenie tohto malého spoločenstva nám priblížila jeho terajšia predstavená setra Klára Havlíková pri osobnej návšteve kláštora; informácie spracované $\mathrm{v}$ tomto článku pochádzajú jednak z jej rozprávania, jednak z webovej stránky tejto rehole a stránky KBS.

Rád klarisiek kapucínok patrí do rehol’nej rodiny sv. Františka a sv. Kláry z Assisi ako druhý kontemplatívny rád s pápežskou klauzúrou. Svoje korene má v 13. storočí v živote týchto dvoch svätcov. Kapucínsku duchovnú rodinu tvorí prvý rád bratov kapucínov, druhý rád - kontemplatívna vetva sestier klarisiek kapucínok a tretí rád - terciári - bratia a sestry žijúci vo svete (laici).

Z histórie tohto rádu sa dozvedáme, že vznikli v 16. storočí. V roku 1535 Maria Laurencia Longo (1463 - 1542) založila skupinu terciáriek, ktoré sa snažili žit pôvodný ideál sv. Kláry z Assisi. 
Aj tu prebehla reforma ako u kapucínov pod heslom - návrat k pôvodnému ideálu sv. Františka a sv. Kláry. Schválenie im udelila Apoštolská stolica a pápež Pavol III. ich uznal 10. decembra 1538 za „kláštor najprísnejšej disciplíny sv. Kláry“. Dušpastierskou starostlivostou o ne poveril bratov kapucínov, odkial pochádza názov kapucínky.

Po zrušení kontemplatívnych rádov zo strany panovníka Jozefa II. v roku 1782 neboli u nás vhodné podmienky pre tento spôsob života. Kto cítil takéto povolanie, mohol ho realizovat iba v zahraničí. Po roku 1990 opät ožila nádej na obnovu kontemplatívneho spôsobu života v reholnom spoločenstve. Po dlhšom hladaní vhodného miesta banskobystrický biskup Rudolf Baláž ponúkol možnost’ pôsobit na území svojej diecézy v obci Kopernica nedaleko Kremnice (Rád klarisiek kapucínok 2019). Dňa 24. 11. 2001 bol kláštor spolu s kaplnkou sv. Kláry konsekrovaný a zasvätený Nepoškvrnenému Srdcu Panny Márie. Forma života v kláštore sestier klarisiek kapucínok vychádza z Regule sv. Kláry z Assisi.

\section{REFERENCES}

Bagin, Anton - Krajči Jozef. 1988. Kostoly a kaplnky hlavného mesta SSR. SSV Trnava.

Čambál, Peter. 2010. Stručný vývoj areálu. In Reštaurátorský výskum fasád areálu Západoslovenského múzea - bývalého klariského kláštora v Trnave. Trnava, 101-102.

Duchoňová, Lucia. 2012. Život klarisiek v Trnave. 1 čast'. In Novinky z radnice 23/6, 16-19.

Esser, Kajetan. 1975. Origini e inizi del movimento e dell'ordine francescano. Storia della chiesa. Milano.

Grundmann, Herbert. 1961. Religiöse Bewegungen im Mittelalter. Neuer Beiträge für Geschichte der religiösen Bewegungen im Mittelalter. Darmstadt.

Karácsony, János. 1923. Szt. Ferencz rendjének története Magyaroszágon 1711. Budapest.

Kósa, Eugen. 1768. Fratris Eugenii Kósa antiquarii Provincia Sanctae Mariae in Hungaria Ordinis minorum S.P.N. Francisci strictioris observantiae cellectanea. Rukopis Univerzitná knižnica v Bratislave. Ms 830.

Kostka, Jiři. 1976. Klariský kostol v Bratislave. Bratislava.

Kušniráková, Ingrid. 2010. Kláštory klarisiek v Uhorsku - alternatíva spoločenského uplatnenia šlachtických žien v ranom novoveku. In Theatrum historiae 7, 7-145.

Kušniráková, Ingrid. 2011. Trnavské klarisky v druhej polovici 18. storočia. In Pamiatky a múzeá 4/2011, 28-32.

Manselli, Raoul. 1965. Rassegna di storia francescana. In Rivista di storia e Letteratura Religiosa 1, 125-137.

Mészárosová, Klára. 2005. Klarissen und Musik nach historischen Quellen aus dem Pressburger und Tyrnauer Kloster. In Konferenzbericht Bratislava, 4. - 5. október 2004. Bratislava, 163-175.

Mészárosová, Klára. 2004/2005. Zrušenie klariského kláštora v Trnave. 1. čast'. In Novinky z radnice 15/11/12, 21-23.

MNL = Magyar Nemzeti Levéltár, Budapest, Országos Levéltár

Némethy, Lajos. 1884. Adatok Árpádházi Boldog Marfit ereklyéinek történetéhez. Budapest.

Oriško, Štefan. 1978. Trnava - bývalý kostol klarisiek. Pamiatkový výskum. Bratislava 1978.

Rád klarisiek kapucínok. 2019. Rád klarisiek kapucínok OSCCap. http://povolania.kbs.sk/ vsetky-cesty/28-kontemplativne-rehole/zenske-kontemplativne-rehole/74-rad-klarisiekkapucinok-osccap.

Roháć, Juraj. 2010. Stredoveká Trnava. In Dejiny Trnavy, I. zväzok. Trnava, 98-100.

Sbaralea, J.H. 1983. Bullarium Franciscanum romanorum pontifucium. Porziuncola. 
Schövitzky, Bartalan. 1886. Adatok a poszonyi gymnasium epületének törtenetéhez: a pozsonyi Klarissza-apáczák törtenete 1297 - 1786. = A pozsonyi Királyi Katholikus Fögymnasium értesitöje az 1885/86 iskolai évröl. Pozsony.

Szyllaba, Emil. 1944. A pozsonyi Klarissza-templom törtenetéhez. Bratislava.

Štátny archív v Batislave (d’alej ŠA Bratislava), fond (dalej f.) Mariánska provincia františkánov (dalej MPF).

Varsík, Branislav. 1994. Vznik Trnavy a rozvoj mesta v stredoveku. Výber štúdií a článkov z rokov 1969 - 1192. Bratislava.

Wadding, Luke.1816. Annales Minorum: Seu Trium Ordinum a S. Francisco institutorum ad 1219 n. 44, ed. 2 (I 1731). Romae.

Zavalloni, Roberto. 2005. Osobnost' Kláry z Assisi. Psychologická štúdia. Bratislava.

SUMMARY: THE ORDER OF SAINT CLARE IN THE KINGDOM OF HUNGARY AND SLOVAKIA. The High Middle Ages was characterized by strong reform movements of religious life. New types of religious communities, so called mendicant (begging) orders, appeared, that practiced many forms of devotion, deeds of love and apostolate. The main objective of all these movements was to follow and imitate Christ. The followers had to leave everything behind and they made a decision to live the life of strict asceticism. Monastery became the symbol of a simple life and seclusion from the world. The growth of this form of religious life peaked in the 12th century with an active participation of female members of religious communities. These movements of intellectual and human restoration were distinctly shaped by the richness of the Franciscan experience. According to Saint Francis of Assisi, poverty is the fundamental basis of the Gospel and Christian life. Saint Francis renounced everything so that he could get closer to the poor, the neglected and the lepers in whom he saw the presence of Christ. He also understood that to live in poverty is not enough, but it must be always combined with mercy and love. St. Francis of Assisi believed that the followers of Christ should not only abandon all worldly delights, but he asked them to renounce any form of ownership. His ideas inspired Saint Clare of Assisi who used Francis's principles to lead the community of nuns for forty years. Saint Clare became the first woman in the history of the Church who wrote a set of instructions for her order called Regula. The Rule was based on the Privilege of Poverty which has been since then followed by all Poor Clares in the world. In 2001, the order of the Capuchin Poor Clares was established in Slovakia in Kopernica near Kremnica.

\author{
ThLic. Mária Nemčeková \\ Faculty of Theology \\ Trnava University in Trnava \\ Kostolná 1 \\ 81101 Bratislava \\ Slovakia \\ maruska.nemcekova@gmail.com
}

